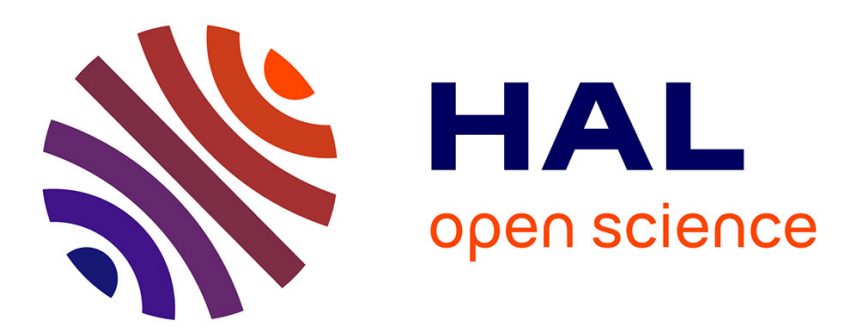

\title{
Outcomes following early red blood cell transfusion in acute upper gastrointestinal bleeding
}

\author{
Sarah A Hearnshaw, Richard F. A. Logan, Kelvin Palmer, Tim R Card, \\ Simon P L Travis, Mike F Murphy
}

\section{- To cite this version:}

Sarah A Hearnshaw, Richard F. A. Logan, Kelvin Palmer, Tim R Card, Simon P L Travis, et al.. Outcomes following early red blood cell transfusion in acute upper gastrointestinal bleeding. Alimentary Pharmacology and Therapeutics, 2010, 32 (2), pp.215. 10.1111/j.1365-2036.2010.04348.x . hal-00552569

\section{HAL Id: hal-00552569 \\ https://hal.science/hal-00552569}

Submitted on 6 Jan 2011

HAL is a multi-disciplinary open access archive for the deposit and dissemination of scientific research documents, whether they are published or not. The documents may come from teaching and research institutions in France or abroad, or from public or private research centers.
L'archive ouverte pluridisciplinaire HAL, est destinée au dépôt et à la diffusion de documents scientifiques de niveau recherche, publiés ou non, émanant des établissements d'enseignement et de recherche français ou étrangers, des laboratoires publics ou privés. 


\begin{tabular}{l}
\hline Alimentary Pharmacology \\
\hline \& Therapeutics \\
\hline
\end{tabular}

\section{Outcomes following early red blood cell transfusion in acute upper gastrointestinal bleeding}

\begin{tabular}{|r|l|}
\hline Journal: & Alimentary Pharmacology \& Therapeutics \\
\hline Manuscript ID: & APT-0220-2010.R1 \\
\hline Manuscript Type: & Original Scientific Paper \\
\hline Author: & Co-Apr-2010 \\
& $\begin{array}{l}\text { Complete List of Authors: } \\
\text { Palmer, Kelvin; Western General Hospital, GI Unit } \\
\text { Card, Tim; University of Nottingham, Epidemiology and Public } \\
\text { Health } \\
\text { Travis, Simon; John Radcliffe Hospital, Gastroenterology } \\
\text { Murphy, Mike; John Radcliffe Hospital, NHS Blood \& Transplant }\end{array}$ \\
\hline \hline Keywords: & $\begin{array}{l}\text { Outcomes research < Topics, Varices < Hepatology, Non-variceal } \\
\text { bleeding < Topics, Peptic ulcer disease < Disease-based }\end{array}$ \\
\hline
\end{tabular}

\section{(5) ScholarONE \\ Manuscript Central}




\title{
Outcomes following early red blood cell transfusion in acute upper gastrointestinal bleeding
}

\author{
S. A. Hearnshaw, MD, MRCP, Clinical Research Fellow ${ }^{1}$ \\ R. F. A. Logan, MSc, FRCP, Professor of Clinical Epidemiology/Consultant \\ Gastroenterologist ${ }^{2}$ \\ K. R. Palmer, MD, FRCP, Consultant Gastroenterologist ${ }^{4}$ \\ T. R. Card, PhD, MRCP, Associate Professor/Consultant Gastroenterologist ${ }^{2}$ \\ S. P. L. Travis, D.Phil, FRCP, Consultant Gastroenterologist ${ }^{3}$ \\ M. F. Murphy, MD, FRCPath, Professor of Transfusion Medicine ${ }^{1}$
}

\begin{abstract}
${ }^{1}$ NHS Blood \& Transplant, John Radcliffe Hospital, Oxford, ${ }^{2}$ Division of Epidemiology and Public Health, University of Nottingham, ${ }^{3}$ Gastroentroenterology Unit, John Radcliffe Hospital, Oxford, ${ }^{4}$ GI Unit, Western General Hospital, Edinburgh
\end{abstract}

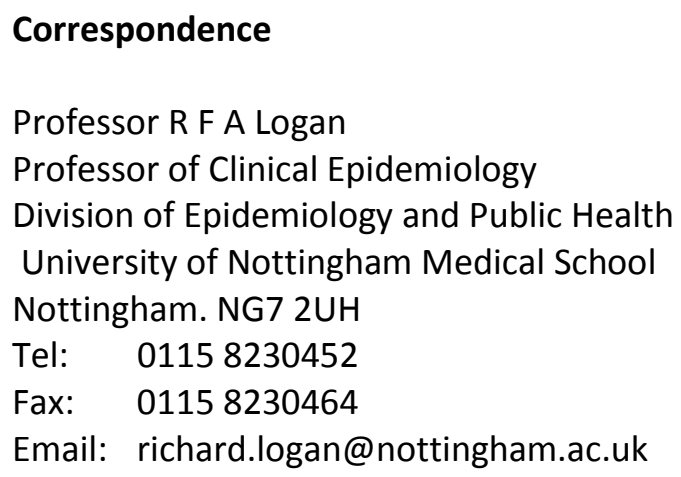




\begin{abstract}
Objective

To examine the relationship between early RBC transfusion, re-bleeding and mortality following acute upper gastrointestinal bleeding (AUGIB), which is one of the commonest indications for red blood cell (RBC) transfusion.

Design

Prospective data collection on a large cohort of patients presenting to UK hospitals with AUGIB. To adjust for case mix the Rockall score was calculated for each patient and used with initial haemoglobin concentration in univariable and multivariable logistic regression models to examine the relationship between early RBC transfusion, re-bleeding and death.

\section{Setting}

All National Health Service (NHS) hospitals accepting acute admissions in the UK $(n=257)$ were invited to participate in the study, and $212(82 \%)$ hospitals submitted data.

\title{
Participants
}

Patients presenting to UK hospitals with AUGIB between $1^{\text {st }}$ May and $30^{\text {th }}$ June 2007 . All patients included had undergone endoscopy.

Results

Of 4441 patients included in the analysis, $44 \%$ received a RBC transfusion within 12 hours of admission. In patients with an initial haemoglobin of $\leqq 8 \mathrm{~g} / \mathrm{dl}$ who were transfused, re-bleeding occurred in $23 \%(234 / 1015,95 \% \mathrm{Cl} 21-26 \%)$ and mortality was $13 \%(130 / 1025,95 \% \mathrm{Cl} 11-15 \%)$ compared with a re-bleeding rate of $15 \%(17 / 111,95 \% \mathrm{Cl} 8.6-22 \%)$ and mortality of $13 \%(14 / 112$, $95 \% \mathrm{Cl} 7.0-20 \%)$ in those not transfused. In patients with an initial haemoglobin $>8 \mathrm{~g} / \mathrm{dl}$ who were transfused, re-bleeding occurred in $24 \%(192 / 812,95 \% \mathrm{Cl} 21-27 \%)$ and mortality was $11 \%(91 / 819$, $95 \% \mathrm{Cl} 9.4 \%-13 \%)$ compared with a re-bleeding rate of $6.7 \%(147 / 2196,95 \% \mathrm{Cl} 5.7-7.8 \%)$ and mortality of $4.3 \%(94 / 2208,95 \% \mathrm{Cl} 3.5 \%-5.2 \%)$ in those not transfused. After adjusting for Rockall score and initial haemoglobin, early transfusion was associated with a two- fold increased risk of re- 
bleeding which was statistically significant, (Odds ratio $2.26,95 \% \mathrm{Cl} 1.76-2.90$ ) and a $28 \%$ increase in mortality (Odds ratio $1.28,95 \% \mathrm{Cl} \quad 0.94-1.74$ ).

\section{Conclusions}

This large prospective study found that early RBC transfusion in AUGIB was associated with a twofold increased risk of re-bleeding and an increase in mortality, although the latter was not statistically significant. Although these findings may be due to confounding factors despite adjustments for case mix and haemoglobin concentration, they indicate that a randomised comparison of restrictive and liberal transfusion policies in AUGIB is urgently required. 


\section{Summary}

\section{What is already known}

- $\quad \mathrm{RBC}$ transfusion in AUGIB accounts for $14 \%$ of units transfused in the UK

- $\quad$ RBC transfusion can be life-saving in exsanguinating AUGIB but in less severe AUGIB bleeding often stops spontaneously

- Evidence is lacking that RBC transfusion is beneficial in less severe AUGIB

New findings

- $44 \%$ of patients with AUGIB receive a RBC transfusion within 12 hours of presentation in the UK

- After adjusting for severity using the Rockall score and initial haemoglobin level rebleeding occurred more than twice as frequently in those transfused within 12 hours compared to those not transfused

- Mortality was also $28 \%$ higher in those having an early RBC transfusion 


\section{Introduction}

Acute upper gastrointestinal bleeding (AUGIB) continues to be a common reason for hospital admission with an annual incidence in the UK of $100-180 / 10^{5} .^{1-3}$ It is also one of the commonest indications for red blood cell (RBC) transfusion, accounting for $14 \%$ of all RBC units transfused in the UK. ${ }^{4} \quad$ Whilst RBC transfusion may be life saving in patients with massive exsanguinating gastrointestinal bleeding the evidence that it is beneficial in less severe bleeding is lacking. Two small trials have failed to demonstrate benefit and one suggested potential harm with increases in re-bleeding, further transfusion and mortality in those receiving early RBC transfusion., ${ }^{5,6}$ Furthermore, in AUGIB secondary to portal hypertension there is evidence that RBC transfusion to levels of $>8 \mathrm{~g} / \mathrm{dl}$ has an adverse effect to the extent that the consensus guidelines strongly recommend maintaining a haemoglobin of around $8 \mathrm{~g} / \mathrm{dl} .^{7}$

There has been extensive work on transfusion triggers in anaemia, but none of these have looked specifically at acute gastrointestinal bleeding. Observational studies and randomised controlled trials of RBC transfusion in other critically ill or bleeding patients have shown little evidence of benefit and some evidence of harm. ${ }^{8-13}$ A randomised controlled trial of the effects of transfusion on critical care outcomes led to the widespread implementation of a restrictive transfusion strategies in critical care. $^{8}$ A systematic review of the published randomized trials of restrictive versus liberal red cell transfusions found significant reductions in blood use in the restrictive groups, without an increase in the rate of adverse clinical outcomes. ${ }^{14}$ Indeed there was a $24 \%$ reduction in adverse cardiac events in the restrictive transfusion group compared with the liberal transfusion group which was of marginal statistical significance. Mortality was also lower (20\%) in the restrictive versus the liberal transfusion group although this was not statistically significant $(p=0.07)$. We report the results of a prospective observational study that examined the hypothesis that RBC transfusion within 12 hours of presentation with AUGIB is independently associated with increased re-bleeding and mortality. 


\section{Methods}

All National Health Service (NHS) hospitals accepting acute admissions in the UK ( $n=257)$ were invited to participate in the study. 223 agreed and 212 (82\%) hospitals submitted data. A list of the hospitals and clinicians contributing data is available at http://www.bsg.org.uk/clinical/general/uk-upper-gi-bleeding-audit.html.

Data were collected prospectively on all adults (16 years or over) who presented with AUGIB between 1 May and 30 June 2007 (Figure 1). For this analysis all patients included had undergone an upper gastrointestinal endoscopy for AUGIB either when it was the presenting condition or when it developed in in-patients. Definitions are provided in Table 1.

A clinical lead in each hospital coordinated a team of case-identifiers and data-collectors. Cases were identified from hospital admission units, endoscopy departments, blood transfusion laboratories and all adult wards by the case-identifiers and preliminary data registered on a purpose designed website. For each patient following discharge or death an online questionnaire was then completed by the designated data collectors. Information on demography, clinical (including medical co-morbidity and risk factors for AUGIB), laboratory, resuscitation, transfusion, endoscopy (including endoscopic therapy, re-bleeding), radiology, surgery, length of stay and mortality was extracted from the hospital records. Each hospital was given a unique login and password. At no time did the study group have access to patient records or any patient-identifying data. Compulsory fields on the questionnaire ensured a minimum dataset for completed eligible cases, which included the variables required to calculate the Rockall score. ${ }^{15}$ This risk score has been internally and externally validated as a predictor of mortality and re-bleeding in patients with AUGIB. ${ }^{16-20}$ and is widely used in the UK.

Data were exported into SPSS for cleaning and analysis, and when necessary hospital clinical leads were contacted to clarify incomplete data. Duplicate cases based on hospital, admission date and time, year of birth and full blood count values were removed from the dataset. Pre- and post- 
endoscopy Rockall scores based upon age, haemodynamic status at presentation, co-morbidity and endoscopic findings (using data from the first inpatient endoscopy following presentation) were calculated for all patients in the analyses presented.

\section{Statistical methods}

For this analysis we excluded patients who received no endoscopy or where data on transfusion within 12 hours or death were incomplete. Initial univariable analyses were then conducted to compare risk factors for re-bleeding and mortality between those receiving and not receiving early RBC transfusion. Re-bleeding was defined as any bleeding occurring after the first endoscopy. Categorical variables are presented as $\%$ (number) with $95 \%$ confidence intervals $(95 \% \mathrm{Cl})$ as necessary and differences were compared by the Chi square test. Normally distributed continuous variables were assessed for normality using a standardised normal probability plot (pnorm command Stata 10) and presented as mean (SD), compared by an unpaired T test. Continuous variables with a skewed distribution are presented as median (interquartile range), tested by the Mann-Whitney test. We examined the proportion of transfused and non-transfused patients who died, stratified for initial haemoglobin concentration and haemodynamic status.

Univariable and then multivariable logistic regression models examined the relationship between early transfusion, re-bleeding and death. Multivariable models were formed both using individual potential confounders alone or in combination and using the calculated Rockall score instead of its individual components. Confounders were retained when their addition produced a $10 \%$ change in the reported effect size. Additional, stratified analyses were conducted to examine for interaction between early transfusion and other factors. All analyses were conducted in Stata SE version 10 (StataCorp, 4905 Lakeway Drive, College Station, Texas 77845 USA) with the exception of the 
calculation of confidence intervals of proportions calculated using $\mathrm{ClA}$ version 2 (University of Southampton).

\section{Results}

\section{$\underline{\text { Participants }}$}

8939 potential cases were registered online. 1199 did not meet entry criteria and were excluded by the local hospital clinical leads. Of the 7740 cases remaining 1190 (14\%) were submitted without sufficient data for analysis and were excluded by the project group. Of the remaining 6750 cases 5004 underwent endoscopy and complete information concerning RBC transfusion was available in 4441 (Figure 1). There were no important differences between the demographic characteristics of the patients included and those excluded due to incomplete data. Patients with missing RBC transfusion data $(n=563)$ had a slightly lower median age (67 yrs, IQR 47-78) vs. 69 yrs, (IQR 52-80); $p=0.005)$ and a higher proportion of female patients ( $44 \%$ vs. $39 \%$ female, $p=0.007)$ ) compared to those with complete transfusion data (data not shown).

$1974 / 4441$ (44\%) of the patient study group received RBC transfusion within 12 hours of presentation. The characteristics of patients who received an early RBC transfusion and those who did not receive early RBC transfusion are shown in Table 2. Patients receiving early transfusion were a mean of 4 years older and were more likely to already be hospital inpatients. Predictably they were also more likely to show signs of haemodynamic instability, have a lower initial haemoglobin level and when endoscoped be found to have peptic ulceration, oesophageal varices or major stigmata of recent bleeding.

\section{Re-bleeding}


Re-bleeding occurred in 15\% (644/4441). Re-bleeding was more commonly recorded in in-patients (22\%) than new admissions $(13 \%, p<0.001)$. As shown in Figure 2 re-bleeding was over twice as common in those receiving an early RBC transfusion as in those not transfused at all levels of complete Rockall scores except for those with scores $>8$. Complete Rockall scores could not be calculated in 12 cases because of incomplete endoscopy data.

\section{$\underline{\text { Re-bleeding and haemoglobin concentration at presentation }}$}

Table 3 shows the relationship between re-bleeding and initial haemoglobin concentration (that first recorded after presentation), early RBC transfusion and the presence of haemodynamic instability (defined as pulse rate 100 beats/min or systolic blood pressure $<100 \mathrm{mmHg}$ at presentation) or haemodynamic stability (pulse rate $<100$ beats/min and systolic blood pressure $>100 \mathrm{mmHg}$ at presentation).

At all levels of initial haemoglobin those receiving an early RBC transfusion had higher rates of rebleeding than those not having early transfusion. In those not transfused the re-bleeding rates declined as the initial haemoglobin rose but in the transfused the re-bleeding rates varied little according to initial haemoglobin.

When stratified by the presence or not of haemodynamic instability re-bleeding rates were predictably higher in those with evidence of haemodynamic instability compared with the stable patients. In both strata re-bleeding rates were higher in the transfused patients irrespective of the initial haemoglobin.

Using a haemoglobin level of $<8 \mathrm{gm} / \mathrm{dl}$ as the threshold level for transfusion as advocated in guidelines for gastrointestinal bleeding, in patients with an initial haemoglobin of $\leqq 8 \mathrm{~g} / \mathrm{dl}$ re-bleeding occurred in $23 \%(234 / 1015,95 \% \mathrm{Cl} 21-26 \%)$ of early transfused patients compared with a re-bleeding rate of $15 \%(17 / 111,95 \% \mathrm{Cl} 8.6-22 \%)$ in those not transfused. In patients with an initial haemoglobin 
$>8 \mathrm{~g} / \mathrm{dl}$ re-bleeding occurred in $24 \%(192 / 812,95 \% \mathrm{Cl} 21-27 \%)$ of early transfused patients compared with a re-bleeding rate of $6.7 \%(147 / 2196,95 \% \mathrm{Cl} 5.7-7.8 \%)$ in those not transfused.

Table 4 shows the unadjusted and adjusted Odds Ratios for re-bleeding after early RBC transfusion. Using the complete Rockall score to adjust for case mix resulted in a reduction in the overall Odds Ratio from $4.05(95 \% \mathrm{Cl} 3.36-4.87)$ to $2.81(95 \% \mathrm{Cl} 2.32-3.42)$ and then adjusting for initial haemoglobin resulted in a further small reduction to $2.26(95 \% \mathrm{Cl} 1.76-2.90)$. The increased Odds Ratios for re-bleeding were greater in the new admissions and in men but were unaffected by excluding patients with variceal bleeding or by excluding those taking low dose aspirin on admission.

\section{Mortality}

Unadjusted mortality for all patients was 7.8\% (346/4441). Mortality was significantly higher among in-patients (20\%) compared to new admissions $(5.4 \%, p<0.001)$. As shown in Figure 2 mortality was greater in patients receiving early RBC transfusion at all levels of the complete Rockall score with the increases being relatively greater with less serious episodes of AUGIB (lower Rockall scores).

Table 5 shows the relationship between mortality and initial haemoglobin concentration, early RBC transfusion and haemodynamic status. As might be expected mortality was greatest in those with an initial haemoglobin of $<5 \mathrm{~g} / \mathrm{dl}(20 \%)$ and lowest in those with levels of $>10 \mathrm{~g} / \mathrm{dl}(5 \%)$ but mortality rates were similar for intermediate levels of initial haemoglobin. In patients with an initial haemoglobin of $\leqq 8 \mathrm{~g} / \mathrm{dl}$ mortality was $13 \%(130 / 1025,95 \% \mathrm{Cl} 11-15 \%)$ in early transfused patients compared with mortality of $13 \%(14 / 112,95 \% \mathrm{Cl} 7.0-20 \%)$ in those not transfused. In patients with an initial haemoglobin $>8 \mathrm{~g} / \mathrm{dl}$ mortality was $11 \%(91 / 819,95 \% \mathrm{Cl} 9.4 \%-13 \%)$ in transfused patients compared with a mortality of $4.3 \%(94 / 2208,95 \% \mathrm{Cl} 3.5 \%-5.2 \%)$ in those not transfused. 
Table 6 shows the unadjusted and adjusted Odds Ratios for mortality after early RBC transfusion.

Using the complete Rockall score to adjust for case mix resulted in a reduction in the overall Odds

Ratio from $2.71(95 \% \mathrm{Cl} 2.14-3.42)$ to $1.50(95 \% \mathrm{Cl} 1.17-1.92)$ and then adjusting for initial

haemoglobin resulted in a further reduction to $1.28(95 \% \mathrm{Cl} 0.94-1.74)$. The addition of urea level and

of the individual components of the Rockall Score to this model either individually or in combination

did not alter the estimate of the OR for early transfusion by the pre-specified $10 \%$ and so these

variables were rejected from the model. 


\section{Discussion}

We have found that patients with AUGIB having a RBC transfusion with 12 hours of admission have a two-fold increased rate of further bleeding and an increased mortality, although the latter was not statistically significant in the fully adjusted model. These observations may be due to an adverse effect of blood transfusion upon haemostasis; they could alternatively be due to differences in case mix between early transfused and non-transfused patients that persisted despite corrections using Rockall scores and haemoglobin concentrations.

The Rockall score was developed to adjust for differences in case mix between hospitals in a previous UK audit of AUGIB management. ${ }^{15}$ Subsequently it has been widely validated and found to be an excellent predictor of mortality, and a reasonable predictor of the risk of re-bleeding. ${ }^{(16-20)}$ It has the advantage of being simple to calculate and is widely used in the UK. In contrast to the Glasgow Blatchford score and some other scores it does not incorporate initial haemoglobin level. ${ }^{(21)}$ We have therefore included initial haemoglobin in our multivariable analysis. As expected, adjusting for Rockall score had a significant impact on the risk estimates for re-bleeding and for mortality as shown in Tables 4 and 6, but addition of initial haemoglobin to the multivariable model had only a modest effect. While we cannot exclude the possibility that our findings can partly be accounted for by residual confounding, this seems unlikely to be sufficient to explain an effect as large as a twofold increase.

The term 're-bleeding' is a widely used end point in publications relating to AUGIB. In reality it is impossible to distinguish with total accuracy gastrointestinal bleeding that ceases and restarts and bleeding that slows and then accelerates or is more continuous. Nevertheless we can think of no reason why any difficulty in detecting or recording of re-bleeding should have introduced bias in our analysis. The doctors extracting data from case records were given clear criteria and definitions for re-bleeding, and while it was clear that one of the objectives of the audit was to examine the use of 
blood products, no pre-specified hypotheses were mentioned. A further strength of the dataset is that data was collected prospectively from a wide range of UK acute hospitals with over threequarters submitting their data. Given this wide coverage there was inevitably some missing data and we cannot be sure that all AUGIB patients were enrolled. Patients not having an endoscopy were also excluded from this analysis. These patients fell into two groups; patients who were critically ill and either had surgery or died before endoscopy and low risk patients who were discharged to have endoscopy as an outpatient. It is difficult to conceive how any of these exclusions would be a source of bias in our analysis. Current guidelines for the management of acute bleeding from varices recommend maintaining a haemoglobin level of approximately $8 \mathrm{~g} / \mathrm{dl}$ and we therefore used this level in the dichotomized analysis. ${ }^{7}$ Using this figure $19 \%(381 / 1973)$ patients receiving an early RBC transfusion had an initial haemoglobin of $>8 \mathrm{~g} / \mathrm{dl}$ and were recorded as being haemodynamically stable. We cannot judge whether these early transfusions were inappropriate or unnecessary but a recently published international consensus statement suggested RBC transfusion was mandatory only when the haemoglobin was $7 \mathrm{~g} / \mathrm{dl}$ or less. ${ }^{22}$

While our findings might appear surprising, blood transfusion has a number of effects beyond replacement of red cells. Adverse effects of blood transfusion such as an increased risk of postoperative infection, acute respiratory distress syndrome, multi-organ failure and mortality have been found, predominantly in large observational studies of blood transfusion and as a nonstatistically significant outcome in a randomised controlled clinical trial in critical care. ${ }^{8,23-25}$ These adverse effects require confirmation in randomised controlled trials, but have been suggested to be due to the effect of leucocytes and biological response modifiers released from leucocytes during the storage of red cell concentrates. ${ }^{23}$ It should be noted that red cell concentrates have been leucocyte-depleted in the UK since 1999, and data were not collected on the storage of red cell concentrates transfused to the patients in this study. 
A small trial in AUGIB which compared liberal transfusion with transfusion only if the haemoglobin concentration fell below $8 \mathrm{~g} / \mathrm{dl}$ found that the percentage of re-bleeding was markedly lower in the restricted transfusion group. ${ }^{5}$ There was evidence of a hypercoaguable response in AUGIB which was reversed by RBC transfusion. There are no clear mechanisms to explain the increased risk of rebleeding associated with blood transfusion found in this previous trial and our study. Loss of one blood volume and replacement with stored red cell concentrates reduces coagulation factors by approximately $70 \%$, but is not generally associated with a bleeding diathesis. ${ }^{26}$ Coagulopathy in massive blood loss is proportional to the volume of blood loss and is multi-factorial, contributed to by activation of the coagulation and fibrinolytic cascades, haemodilution, hypothermia, impaired hepatic synthesis of coagulation factors, release of tissue factor into circulation, endothelial cell damage activating intravascular coagulation and DIC, acidosis from haemorrhagic shock, hypovolaemia and transfusions, and impaired clearance of activated coagulation factors resulting from shock. ${ }^{27}$ In addition, the patients in this study with AUGIB associated with chronic liver disease and portal hypertension would be likely to have pre-existing abnormal coagulation and thrombocytopenia due to poor hepatic synthetic function and hypersplenism, respectively. Paradoxically, red cell transfusion has been shown to restore anaemia-induced prolonged bleeding times to normal in normal volunteers, and to reduce blood loss in patients after cardiac surgery although this effect may depend on storage of red cells for no longer than 14 days. ${ }^{28}$ Red cell concentrates are currently stored for up to 35 days in the UK, although most are transfused well before 35 days; as mentioned, data on the storage of red cell concentrates were not collected in this study.

This is an observational study and it is still possible that the two fold increase in re-bleeding found after early RBC transfusion reflects residual confounding i.e. the decision to give an early RBC transfusion reflects a clinical assessment of the risk of re-bleeding for which adjustment with the Rockall score and haemoglobin level has been insufficient. While this possibility maybe plausible at 
lower levels of haemoglobin at higher levels it seems most unlikely that the decision to transfuse early, often made by relatively inexperienced doctors reflects a clinical assessment of risk not captured by the Rockall score and of sufficient magnitude to be associated with a two fold increase. A definitive answer to this requires a randomised trial. In several other conditions randomised trials comparing restrictive with liberal transfusion policies have shown some benefits favouring restrictive transfusion. ${ }^{14}$ In AUGIB two small trials have supported restrictive transfusion. ${ }^{6,7}$ A third larger trial, as yet not fully reported has found that in patients with AUGIB and portal hypertension a restrictive transfusion policy in which $38 \%$ were not transfused was associated with significantly increased survival and fewer side-effects compared with a liberal policy in which only $9 \%$ were not transfused. ${ }^{29}$ Our study strongly suggests that many patients presenting with AUGIB and a haemoglobin of $>8 \mathrm{~g} / \mathrm{dl}$ do not benefit from early RBC transfusion, and we believe a large trial of restrictive and liberal transfusion policies is now required.

\section{Funding}

This research fellow for this study (SH) was funded by NHS Blood and Transplant and the British Society of Gastroenterology. Representatives from each of these groups, (MM and KP) were involved in the design and reporting of the study (see contributorship statement). Participating hospitals did not receive any financial support.

\section{Contributorship statement}

SH was the study lead, designed and conducted the study, and wrote the manuscript.

RL was involved in the study design, wrote the manuscript and is a guarantor.

KP had the original idea for the study, and was involved in study design and reporting.

TC provided statistical input to the study.

ST was involved in study design and reporting. 
MM had the original idea for the study, was involved in study design, wrote the manuscript and is a guarantor. 


\section{References}

1. Rockall TA, Logan RFA, Devlin HB, Northfield TC on behalf of the steering committee and members of the National Audit of Acute Gastrointestinal Haemorrhage. Incidence of and mortality from acute upper gastrointestinal haemorrhage in the United Kingdom. BMJ 1995; 311: 222-226.

2. Blatchford O, Davidson LA, Murray WR, Blatchford M, Pell J. Acute upper gastrointestinal haemorrhage in west of Scotland: case ascertainment study. BMJ 1997;315:510-514

3. Taha AS, Angerson WJ, Prasad R, McCloskey C, Blatchford O. Upper gastrointestinal bleeding and the changing use of COC-2 non-steroidal anti-inflammatory drugs and low-dose aspirin. Aliment Pharmacol Ther 26;1171-1178

4. Wallis JP, Wells AW, Chapman CE. Changing indications for red cell transfusion from 2000 to 2004 in the North of England. Transfusion Med 2006; 16: 411-417

5. Blair SD, Janvrin SB, McCollum CN et al. Effect of early blood transfusion on gastrointestinal haemorrhage. Br J Surg 1986; 73: 783-85.

6. Villarejo DF, Rizzolo M, Lopez E et al. Acute anemia in high digestive hemorrhage. Margins of security for their handling without transfusion of red globules. Acta Gastroenterol Latinoam 1999; 29: 261-270

7. De Franchis R. Evolving consensus in portal hypertension. Report of the Baveno IV Consensus Workshop on methodology of diagnosis and therapy in portal hypertension. J Hepatol 2005; 43:167-176.

8. Hebert PC, Wells G, Blajchman MA et al. A multicenter, randomized, controlled clinical trial of transfusion requirements in critical care. N Engl J Med 1999; 340: 409-17.

9. Lacroix J, Hebert M, Hutchinson J et al. Transfusion strategies for patients in pediatric intensive care units. N Engl J Med 2008; 356: 1609-19.

10. Murphy G, Reeves B, Rogers C, Rizvi S, Culliford L, Angelini G. Increased mortality, postoperative morbidity, and cost after red blood cell transfusion in patients having cardiac surgery. Circulation 2007; 116: 2544-2552.

11. Taylor RW, Manganaro L, O'Brien J, Trottier SJ, Parkar N, Veremakis C. Impact of allogeneic packed red blood cell transfusion on nosocomial infection rates in the critically ill patient. Crit Care Med 2002; 30: 2249-54.

12. Malone DL, Dunne J, Tracy JK, Putnam AT, Scalea TM, Napolitano LM. Blood transfusion, independent of shock severity, is associated with worse outcome in trauma. J Trauma 2003; 54: 898-905. 
13. Robinson WP III, Ahn J, Stiffler A et al. Blood transfusion is an independent predictor of increased mortality in non-operatively managed blunt hepatic and splenic injuries. J Trauma 2005; 58: 437 44.

14. Hill SR, Carless PA, Henry DA et al. Transfusion thresholds and other strategies for guiding allogeneic red blood cell transfusion. Cochrane Database of Systematic Reviews 2000, Issue 1.

15. Rockall TA, Logan RF, Devlin HB, Northfield TC. Risk assessment after acute upper gastrointestinal haemorrhage. Gut 1996; 38: 316-21

16. Vreeburg EM, Terwee CB, Snel P, Rauws EA, Bartelsman JF, vd Meulen JH, Tytgat GN. Validation of the Rockall risk scoring system in upper gastrointestinal bleeding. Gut 1999; 44: 331-355

17. Church NI, Dallal HJ, Masson J, Mowat NA, Johnston DA, Radin E, Turner M, Fullarton G, Prescott RJ, Palmer KR. Validity of the Rockall scoring system after endoscopic therapy for bleeding peptic ulcer: a prospective cohort study.

18. Sanders DS, Carter MJ, Goodchap RJ et al. Prospective validation of the Rockall risk scoring system for upper GI haemorrhage in subgroups of patients with varices and peptic ulcers. Am J Gastroenterol 2002; 97: 630-635.

19. Enns RA, Gagnon YM, Barkan AN et al. Validation of the Rockall scoring system for outcomes from non-variceal upper gastrointestinal bleeding in a Canadian setting. World J Gastroenterol 2006; 12: 7779-7785.

20. Sarwar S, Dilshad A, Khan A et al. Predictive value of Rockall score for re-bleeding and mortality in patients with variceal bleeding. J Coll Physicians Surg Pak 2007; 17: 253-256.

21. Blatchford O, Murray WR, Blatchford MA. A risk score to predict need for treatment for upper gastrointestinal haemorrhage. Lancet 2000; 356: 1318-21.

22. Barkun AN, Bardou M, Kuipers EJ, Sung J, Hunt RH, Matel M, Sinclair P. International consensus recommendations on the management of patients with nonvariceal upper gastrointestinal bleeding. Ann Intern Med 2010;152:101-113.

23. Vamvakas EC, Blajchman MA. Transfusion-related mortality: the ongoing risks of allogeneic blood transfusion and the available strategies for their prevention. Blood; prepublished online February 2, 2009: doi 10.1182/blood-2008-10-167643.

24. Chaiwat O, Lang JD, Vavilala MS, Wang J, MacKenzie EJ, Jurkovich GJ, Rivara FP. Early packed red blood cell transfusion and acute respiratory distress syndrome after trauma. Anesthesiology 2009; 110: 351-360.

25. Koch C, Liang L, Sessler D, Figueroa P et al. Duration of red-cell storage and complications after cardiac surgery. N Engl J Med 2008; 358: 1229-39. 
26. Hiippala ST, Myllyla GJ, Vahtera EM. Hemostatic factors and replacements if major blood loss with plasma-poor red cell concentrates. Anaesth Analg 1995; 81: 360-65.

27. Hardy JF, de Moerloose P, Samama CM. The coagulopathy of massive transfusion. Vox Sang 2005; 89: 123-127.

28. Valeri CR, Khuri S, Ragno G. Nonsurgical bleeding diathesis in anemic thrombocytopenic patients: role of temperature, red blood cells, platelets and plasma-clotting proteins. Transfusion 2007; 47: 206S-248S.

29. Colomo A, Hernandez-Gea V, Muniz-Diaz E, Madoz P, Aracil C. et al. Transfusion strategies in patients with cirrhosis and acute gastrointestinal bleeding. Hepatology 2008; 48: 413A. 
Figure 1: Flow chart of how cases were identified for inclusion in study

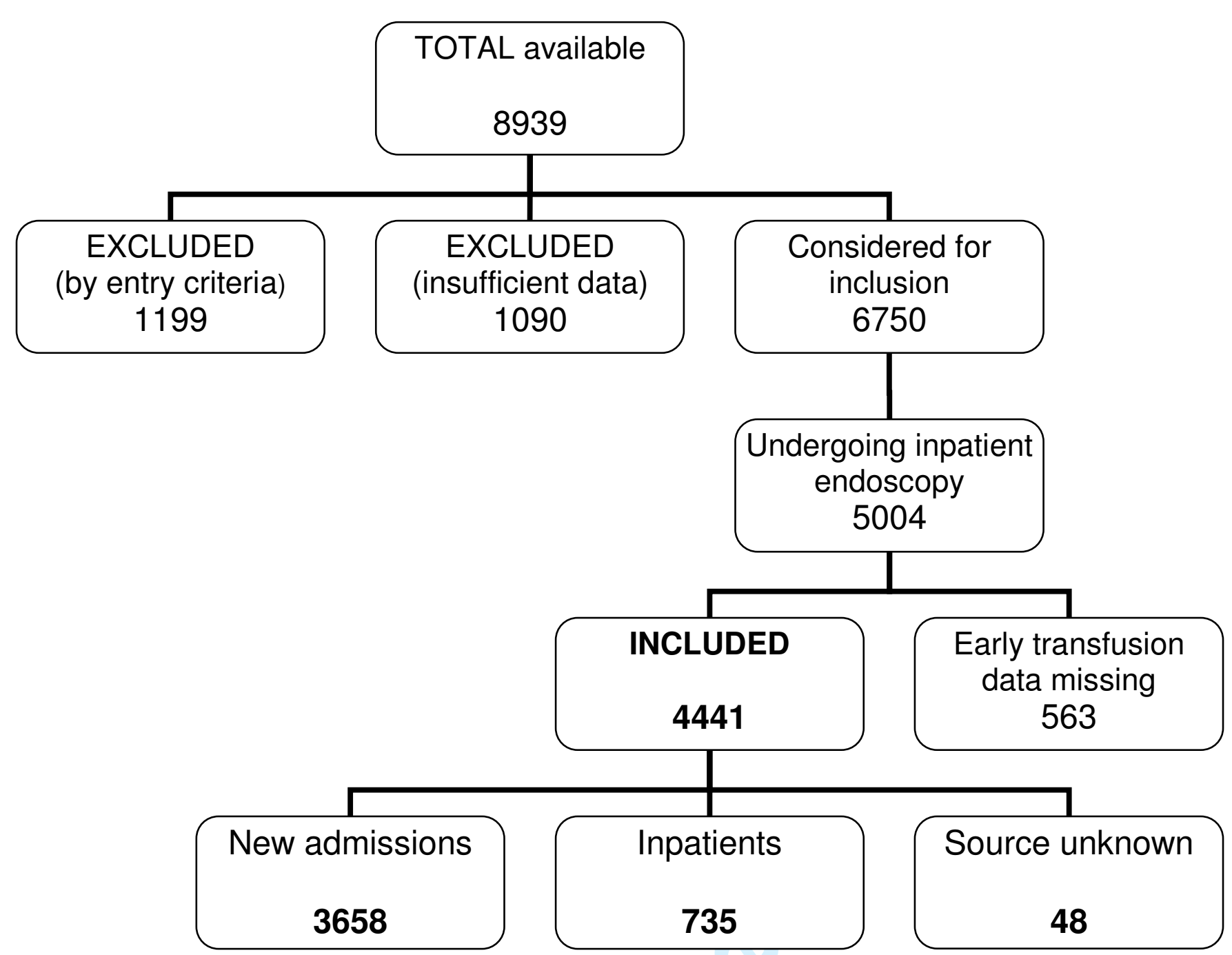


Figure 2: Re-bleeding and mortality by complete Rockall in those receiving early $\mathrm{RBC}$ transfusion and those not receiving early $\mathrm{RBC}$ transfusion
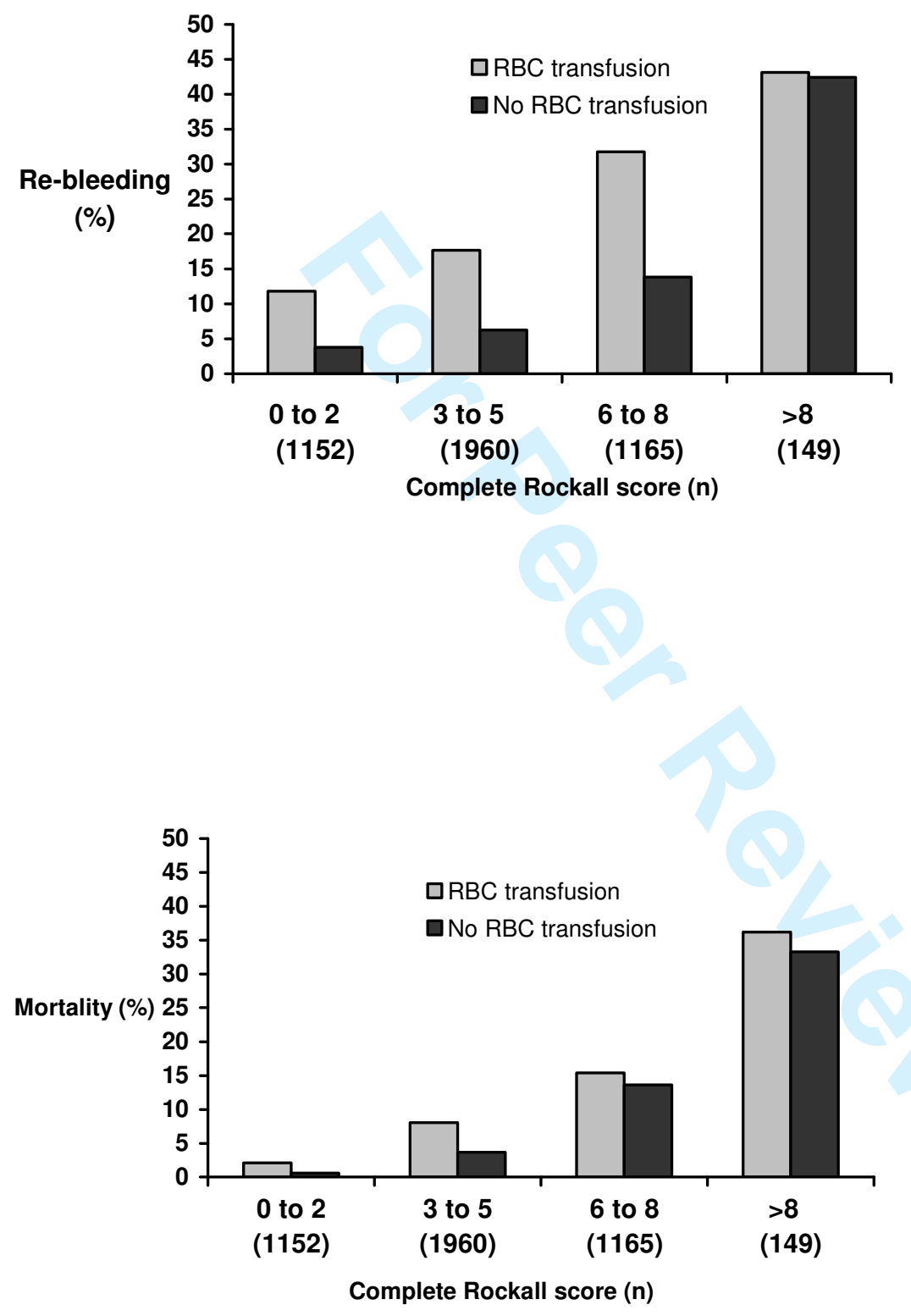


\section{Table 1: Definitions used in the study of RBC transfusion and AUGIB}

Acute upper gastrointestinal bleeding (AUGIB)

Haematemesis, the passage of melaena and/or firm clinical or laboratory evidence of acute blood loss from the UGI tract. Patients presenting with iron deficiency anaemia without evidence of AUGIB were not included.

Early red blood cell (RBC) transfusion

RBC transfusion within 12 hours of presentation with AUGIB.

Re-bleeding

Further haematemesis, passage of fresh melaena, continuing or recurring hypotension and tachycardia

$+/$ - fall in haemoglobin after the first endoscopy

All cause mortality

Death occurring within the hospital admission up to 30 days post index AUGIB 
Table 2: Patient characteristics - early RBC transfusion vs. no early RBC transfusion

\begin{tabular}{|c|c|c|c|}
\hline Variable & $\begin{array}{c}\text { Early RBC } \\
\text { transfusion } \\
n=1974 \\
\%(n)\end{array}$ & $\begin{array}{c}\text { No early RBC } \\
\text { transfusion } \\
n=2467 \\
\%(n)\end{array}$ & $\mathbf{p}$ \\
\hline \multicolumn{4}{|l|}{ Presentation } \\
\hline New admission & $80(1576)$ & $84(2082)$ & $<0.001$ \\
\hline Inpatient & $19(375)$ & $15(360)$ & \\
\hline Unknown & $1(23)$ & $1(25)$ & \\
\hline \multicolumn{4}{|l|}{ Age years } \\
\hline mean (SD) & $67.9(16.51)$ & $63.4(19.19)$ & $<0.001$ \\
\hline Female & $39(762)$ & $39(948)$ & 0.536 \\
\hline Haemodynamic status & & & $<0.001$ \\
\hline Normal & $46(914)$ & $68(1679)$ & \\
\hline Tachycardia only & $26(507)$ & $24(595)$ & \\
\hline $\mathrm{BP}<100>70$ & $23(450)$ & $7(168)$ & \\
\hline $\mathrm{BP}<70>50$ & $3(64)$ & $0(9)$ & \\
\hline $\mathrm{BP}<50$ & $1(17)$ & $0(0)$ & \\
\hline Not recorded & 1. (22) & $1(16)$ & \\
\hline \multicolumn{4}{|c|}{ First recorded haemoglobin } \\
\hline \multicolumn{4}{|l|}{ concentration $\mathrm{g} / \mathrm{dL}$} \\
\hline$>10.1$ & $15(292)$ & $74(1830)$ & $<0.001$ \\
\hline $8.1-10.0$ & $27(527)$ & $15(381)$ & \\
\hline $7.1-8.0$ & $19(376)$ & $3(71)$ & \\
\hline$<=7.0$ & $33(649)$ & $1.2(41)$ & \\
\hline Not recorded & $7(130)$ & $6(144)$ & \\
\hline Mean $\mathrm{Hb}(\mathrm{SD})$ & $8.0(2.16)$ & $12(2.54)$ & $<0.001$ \\
\hline \multicolumn{4}{|l|}{ Co-morbidity } \\
\hline IHD & $23(456)$ & $17(425)$ & $<0.001$ \\
\hline Cardiac failure & $7(139)$ & $5(119)$ & 0.002 \\
\hline Respiratory disease & $11(217)$ & $11(263)$ & 0.697 \\
\hline Cirrhosis & $15(295)$ & $8(192)$ & $<0.001$ \\
\hline Renal disease & $11(208)$ & $6(159)$ & $<0.001$ \\
\hline Stroke & $6(117)$ & $8(189)$ & 0.027 \\
\hline \multicolumn{4}{|c|}{ Pre endoscopy Rockall score } \\
\hline $0-1$ & 19 (375) & 39 (959) & $<0.001$ \\
\hline $2-3$ & $34(669)$ & $32(787)$ & \\
\hline
\end{tabular}




\begin{tabular}{|c|c|c|c|}
\hline $4-5$ & $37(737)$ & $26(652)$ & \\
\hline $6-7$ & $10(193)$ & $3(69)$ & \\
\hline Rockall >3 & $47(930 / 1974)$ & $29(721 / 2467)$ & $<0.001$ \\
\hline \multicolumn{4}{|l|}{ Medication } \\
\hline Aspirin & $35(657)$ & $29(693)$ & $<0.001$ \\
\hline NSAID & $14(261)$ & $12(293)$ & 0.170 \\
\hline Warfarin & $10(199)$ & $6(138)$ & $<0.001$ \\
\hline Median time to endoscopy & $19(8-43)$ & $25(15-59)$ & $<0.001$ \\
\hline \multicolumn{4}{|l|}{ hours (IQR) } \\
\hline \multicolumn{4}{|l|}{ Endoscopic diagnosis } \\
\hline Peptic ulcer & $44(862)$ & $31(750)$ & $<0.001$ \\
\hline Varices & $16(320)$ & $7(177)$ & $<0.001$ \\
\hline MSRH & 49 (957) & $21(517)$ & $<0.001$ \\
\hline \multicolumn{4}{|l|}{$\underline{\text { Complete Rockall score }}^{*}$} \\
\hline $0-2$ & $14(279)$ & $36(873)$ & \\
\hline $3-5$ & $42(831)$ & $46(1132)$ & \\
\hline $6-8$ & $38(747)$ & $17(418)$ & \\
\hline$>8$ & $6(116)$ & $1(33)$ & $<0.001$ \\
\hline Rockall $>5$ & $44(863 / 1973)$ & $18(451 / 2456)$ & $<0.001$ \\
\hline \multicolumn{4}{|l|}{ Initial urea $(\mathrm{mmol} / \mathrm{l})$} \\
\hline$\underline{0-6.5}$ & $19(370)$ & $38(942)$ & \\
\hline$\underline{6.6-8.0}$ & $9(174)$ & $9(223)$ & \\
\hline$\underline{8.1-10}$ & $11(208)$ & $11(273)$ & \\
\hline$\underline{10.1-25}$ & $41(807)$ & $28(690)$ & \\
\hline$\geq 25$ & $10(205)$ & $4(96)$ & \\
\hline$\underline{\text { Unrecorded }}$ & $11(209)$ & $10(243)$ & $<0.001$ \\
\hline
\end{tabular}

$\mathrm{BP}$ - systolic blood pressure $\mathrm{mm} \mathrm{Hg}$

IHD - ischaemic heart disease

NSAID - non-steroidal antiinflammatory drug

$\mathrm{MSRH}$ - major stigmata of recent haemorrhage

*in 12 cases complete Rockall score could not be calculated as endoscopic findings were not submitted 
Table 3: Early RBC transfusion, initial haemoglobin concentration, haemodynamic status and re-bleeding

First recorded haemoglobin concentration (g/dL)$$
(g / d L)
$$

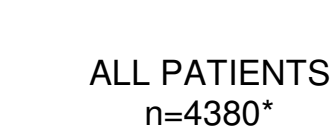

RBC No RBC transfusion transfusion $n=1950 \quad n=2430$ Haemodynamically
UNSTABLE $\mathrm{n}=1786$

RBC No RBC transfusion transfusion $n=757 \quad n=1029$
Haemodynamically STABLE $\mathrm{n}=2560$

RBC No RBC transfusion transfusion $n=903 \quad n=1657$

\begin{tabular}{|c|c|c|c|c|c|c|c|}
\hline $\mathrm{Hb}$ missing & Rebled & $38 / 128$ & $13 / 138$ & $22 / 77$ & $7 / 41$ & $15 / 46$ & $6 / 94$ \\
\hline & $\begin{array}{c}\text { Rate } \\
(95 \% \mathrm{Cl})\end{array}$ & $\begin{array}{c}30 \% \\
(22-38)\end{array}$ & $\begin{array}{c}9.4 \% \\
(5-14)\end{array}$ & $\begin{array}{c}28 \% \\
(18-38)\end{array}$ & $\begin{array}{c}17 \% \\
(5-28)\end{array}$ & $\begin{array}{c}33 \% \\
(19-46)\end{array}$ & $\begin{array}{c}6.4 \% \\
(1-11)\end{array}$ \\
\hline \multirow[t]{2}{*}{$\leq 5.0$} & Rebled & $34 / 120$ & $0 / 2$ & $27 / 74$ & $0 / 2$ & $7 / 45$ & $0 / 0$ \\
\hline & $\begin{array}{c}\text { Rate } \\
(95 \% \mathrm{Cl})\end{array}$ & $\begin{array}{c}28 \% \\
(20-36)\end{array}$ & $0 \%$ & $\begin{array}{c}36 \% \\
(26-47)\end{array}$ & $0 \%$ & $\begin{array}{c}16 \% \\
(5-26)\end{array}$ & - \\
\hline \multirow[t]{2}{*}{$5.1-7.0$} & Rebled & $123 / 520$ & $6 / 39$ & $82 / 263$ & $3 / 13$ & $40 / 257$ & $3 / 25$ \\
\hline & $\begin{array}{c}\text { Rate } \\
(95 \% \mathrm{Cl})\end{array}$ & $\begin{array}{c}24 \% \\
(20-27)\end{array}$ & $\begin{array}{c}15 \% \\
(4-27)\end{array}$ & $\begin{array}{c}31 \% \\
(26-37)\end{array}$ & $\begin{array}{c}23 \% \\
(5-54)\end{array}$ & $\begin{array}{c}16 \% \\
(11-20)\end{array}$ & $\begin{array}{c}12 \% \\
(3-31)\end{array}$ \\
\hline \multirow[t]{2}{*}{$7.1-8.0$} & Rebled & $78 / 374$ & $11 / 71$ & $52 / 188$ & $6 / 22$ & $26 / 183$ & $5 / 49$ \\
\hline & $\begin{array}{c}\text { Rate } \\
(95 \% \mathrm{Cl})\end{array}$ & $\begin{array}{c}21 \% \\
(17-25)\end{array}$ & $\begin{array}{c}15 \% \\
(8-26)\end{array}$ & $\begin{array}{c}28 \% \\
(21-34)\end{array}$ & $\begin{array}{c}27 \% \\
(11-50)\end{array}$ & $\begin{array}{c}14 \% \\
(9-20)\end{array}$ & $\begin{array}{c}10 \% \\
(3-22)\end{array}$ \\
\hline \multirow[t]{2}{*}{$8.1-10.0$} & Rebled & $116 / 518$ & $43 / 375$ & $70 / 251$ & $13 / 116$ & $45 / 264$ & $30 / 258$ \\
\hline & $\begin{array}{c}\text { Rate } \\
(95 \% \mathrm{Cl})\end{array}$ & $\begin{array}{c}22 \% \\
(19-26)\end{array}$ & $\begin{array}{c}11 \% \\
(8-15)\end{array}$ & $\begin{array}{c}28 \% \\
(22-34)\end{array}$ & $\begin{array}{c}11 \% \\
(5-17)\end{array}$ & $\begin{array}{c}17 \% \\
(13-22)\end{array}$ & $\begin{array}{c}12 \% \\
(8-16)\end{array}$ \\
\hline \multirow[t]{2}{*}{$10.1+$} & Rebled & $78 / 290$ & $104 / 1805$ & $49 / 178$ & $49 / 563$ & $28 / 111$ & $55 / 1234$ \\
\hline & $\begin{array}{c}\text { Rate } \\
(95 \% \mathrm{Cl})\end{array}$ & $\begin{array}{c}27 \% \\
(22-32)\end{array}$ & $\begin{array}{l}5.8 \% \\
(5-7)\end{array}$ & $\begin{array}{c}28 \% \\
(21-35)\end{array}$ & $\begin{array}{c}8.7 \% \\
(6-11)\end{array}$ & $\begin{array}{c}25 \% \\
(17-34)\end{array}$ & $\begin{array}{l}4.5 \% \\
(3-6)\end{array}$ \\
\hline
\end{tabular}

${ }^{*}$ Data on re-bleeding missing in 61, haemoglobin concentration at presentation missing in 266 patients and data on haemodynamic status missing in a further 34 $\mathrm{Hb}$ - haemoglobin concentration 
Table 4: Unadjusted and adjusted odds ratios for re-bleeding after transfusion within 12 hours by subgroup for patients receiving early RBC transfusion

\begin{tabular}{|c|c|c|c|}
\hline Patient group (n) & $\begin{array}{l}\text { Unadjusted re- } \\
\text { bleeding odds } \\
\text { ratio }(95 \% \mathrm{Cl})\end{array}$ & $\begin{array}{c}\text { Adjusted by } \\
\text { Rockall score } \\
(95 \% \mathrm{Cl})\end{array}$ & $\begin{array}{l}\text { Adjusted by Rockall score and } \\
\text { haemoglobin concentation } \\
\qquad(95 \% \mathrm{Cl})\end{array}$ \\
\hline Inpatients (708) & $2.28(1.57-3.30)$ & $1.70(1.16-2.52)$ & $1.35(0.84-2.16)$ \\
\hline $\begin{array}{l}\text { New Admissions } \\
(3518)\end{array}$ & $4.68(3.76-5.83)$ & $3.27(2.60-4.11)$ & 2.77 (2.07-3.73) \\
\hline Female (1646) & 3.45 (2.54-4.69) & $2.54(1.85-3.50)$ & $2.00(1.34-3.00)$ \\
\hline Male (2629) & $4.42(3.50-5.58)$ & $2.96(2.31-3.79)$ & $2.33(1.69-3.20)$ \\
\hline $\begin{array}{l}\text { Excluding patients } \\
\text { with varices }(3820)\end{array}$ & $4.03(3.29-4.93)$ & $2.89(2.34-3.57)$ & $2.15(1.63-2.83)$ \\
\hline $\begin{array}{l}\text { Excluding patients } \\
\text { on aspirin (2949) }\end{array}$ & $4.36(3.50-5.44)$ & $2.86(2.26-3.61)$ & $2.41(1.77-3.27)$ \\
\hline Total (4276) & $4.05(3.36-4.87)$ & $2.81(2.32-3.42)$ & $2.26(1.76-2.90)$ \\
\hline
\end{tabular}

* $\mathrm{n}$ is dependent on number of cases with complete and usable data for all components of logistic regression. Missing data vary between outcomes making $n$ variable. 
Table 5: Early RBC transfusion, haemoglobin concentration, haemodynamic status and mortality

\begin{tabular}{|c|c|c|c|c|c|c|c|}
\hline \multirow{2}{*}{$\begin{array}{l}\text { First recorded } \\
\text { haemoglobin } \\
\text { concentration } \\
(\mathrm{g} / \mathrm{dL})\end{array}$} & & \multicolumn{2}{|c|}{$\begin{array}{c}\text { ALL PATIENTS } \\
\mathrm{n}=4441^{*}\end{array}$} & \multicolumn{2}{|c|}{$\begin{array}{l}\text { Haemodynamically } \\
\text { UNSTABLE } n=1810\end{array}$} & \multicolumn{2}{|c|}{$\begin{array}{l}\text { Haemodynamically } \\
\text { STABLE } n=2593\end{array}$} \\
\hline & & $\begin{array}{c}\mathrm{RBC} \\
\text { transfusion } \\
\mathrm{n}=1974\end{array}$ & $\begin{array}{c}\text { No RBC } \\
\text { transfusion } \\
n=2467\end{array}$ & $\begin{array}{c}\mathrm{RBC} \\
\text { transfusion } \\
\mathrm{n}=1038\end{array}$ & $\begin{array}{c}\text { No } R B C \\
\text { transfusion } \\
n=772\end{array}$ & $\begin{array}{c}\mathrm{RBC} \\
\text { transfusion } \\
\mathrm{n}=1679\end{array}$ & $\begin{array}{c}\text { No } R B C \\
\text { transfusion } \\
n=914\end{array}$ \\
\hline \multirow[t]{2}{*}{$\mathrm{Hb}$ missing } & Died & $9 / 130$ & $7 / 144$ & $7 / 79$ & $4 / 42$ & $2 / 46$ & $3 / 99$ \\
\hline & $\begin{array}{l}\text { Mortality } \\
(95 \% \mathrm{Cl})\end{array}$ & $\begin{array}{l}6.9 \% \\
(3-11)\end{array}$ & $\begin{array}{l}4.9 \% \\
(1-8)\end{array}$ & $\begin{array}{l}8.9 \% \\
(3-15)\end{array}$ & $\begin{array}{l}9.5 \% \\
(1-18)\end{array}$ & $\begin{array}{l}4.4 \% \\
(0-10)\end{array}$ & $\begin{array}{l}3.0 \% \\
(0-6)\end{array}$ \\
\hline \multirow[t]{2}{*}{$\leq 5.0$} & Died & $24 / 124$ & $1 / 2$ & $20 / 76$ & $1 / 2$ & $4 / 46$ & 0 \\
\hline & $\begin{array}{l}\text { Mortality } \\
(95 \% \mathrm{Cl})\end{array}$ & $\begin{array}{c}19 \% \\
(13-27)\end{array}$ & $\begin{array}{c}50 \% \\
(10-91)\end{array}$ & $\begin{array}{c}26 \% \\
(18-37)\end{array}$ & $\begin{array}{c}50 \% \\
(10-91)\end{array}$ & $\begin{array}{l}8.7 \% \\
(3-20)\end{array}$ & - \\
\hline \multirow[t]{2}{*}{$5.1-7.0$} & Died & $61 / 525$ & $3 / 39$ & $42 / 263$ & $2 / 13$ & $19 / 257$ & $1 / 25$ \\
\hline & $\begin{array}{l}\text { Mortality } \\
(95 \% \mathrm{Cl})\end{array}$ & $\begin{array}{c}12 \% \\
(9-15)\end{array}$ & $\begin{array}{l}7.7 \% \\
(0-16)\end{array}$ & $\begin{array}{c}16 \% \\
(12-21)\end{array}$ & $\begin{array}{c}15 \% \\
(4-42)\end{array}$ & $\begin{array}{l}7.4 \% \\
(4-11)\end{array}$ & $\begin{array}{l}4.0 \% \\
(0-12)\end{array}$ \\
\hline \multirow[t]{2}{*}{$7.1-8.0$} & Died & $45 / 376$ & $10 / 71$ & $29 / 189$ & $4 / 22$ & $15 / 184$ & $6 / 49$ \\
\hline & $\begin{array}{l}\text { Mortality } \\
(95 \% \mathrm{Cl})\end{array}$ & $\begin{array}{c}12 \% \\
(9-16)\end{array}$ & $\begin{array}{c}14 \% \\
(8-24)\end{array}$ & $\begin{array}{c}15 \% \\
(11-21)\end{array}$ & $\begin{array}{c}18 \% \\
(7-39)\end{array}$ & $\begin{array}{l}8.2 \% \\
(4-12)\end{array}$ & $\begin{array}{c}12 \% \\
(3-21)\end{array}$ \\
\hline \multirow[t]{2}{*}{$8.1-10.0$} & Died & $56 / 527$ & $27 / 381$ & $38 / 253$ & $10 / 118$ & $18 / 268$ & $16 / 262$ \\
\hline & $\begin{array}{l}\text { Mortality } \\
(95 \% \mathrm{Cl})\end{array}$ & $\begin{array}{c}11 \% \\
(8-14)\end{array}$ & $\begin{array}{l}7.1 \% \\
(5-10)\end{array}$ & $\begin{array}{c}15 \% \\
(11-21)\end{array}$ & $\begin{array}{l}8.5 \% \\
(3-14)\end{array}$ & $\begin{array}{l}6.7 \% \\
(4-10)\end{array}$ & $\begin{array}{l}6.1 \% \\
(3-9)\end{array}$ \\
\hline \multirow[t]{2}{*}{$10.1+$} & Died & $35 / 292$ & $67 / 1830$ & $29 / 179$ & $34 / 575$ & $6 / 113^{* *}$ & $33 / 1244$ \\
\hline & $\begin{array}{l}\text { Mortality } \\
(95 \% \mathrm{Cl})\end{array}$ & $\begin{array}{c}12 \% \\
(9-16)\end{array}$ & $\begin{array}{l}3.7 \% \\
(3-5)\end{array}$ & $\begin{array}{c}16 \% \\
(11-22)\end{array}$ & $\begin{array}{l}5.9 \% \\
(4-9)\end{array}$ & $\begin{array}{l}5.3 \% \\
(1-9)\end{array}$ & $\begin{array}{l}2.6 \% \\
(2-4)\end{array}$ \\
\hline
\end{tabular}

*Data on haemoglobin concentration at presentation missing in 274 patients and data on haemodynamic status missing in further 38

${ }^{* *}$ It is unclear from the data submitted what the clinical indication for transfusion was in these patients 
Table 6: Subgroup analyses: Unadjusted and adjusted odds ratios for mortality after transfusion within 12 hours by sub-group of patients receiving early RBC transfusion

\begin{tabular}{lccc}
\hline Patient group $\left(\mathbf{n}^{*}\right)$ & $\begin{array}{c}\text { Unadjusted } \\
\text { mortality odds } \\
\text { ratio }(95 \% \mathrm{Cl})\end{array}$ & $\begin{array}{c}\text { Adjusted by } \\
\text { Rockall score } \\
(95 \% \mathrm{Cl})\end{array}$ & $\begin{array}{c}\text { Adjusted by Rockall score } \\
\text { and haemoglobin } \\
\text { concentration } \\
(95 \% \mathrm{Cl})\end{array}$ \\
\hline Inpatients (722) & $1.70(1.17-2.46)$ & $1.21(0.84-1.78)$ & $1.33(0.83-2.13)$ \\
New Admissions (3596) & $3.35(2.45-4.59)$ & $1.78(1.27-2.49)$ & $1.40(0.92-2.13)$ \\
\hline Female (1714) & $2.31(1.63-3.29)$ & $1.50(1.03-2.16)$ & $1.29(0.82-2.03)$ \\
Male (2727) & $3.06(2.23-4.17)$ & $1.50(1.07-2.11)$ & $1.31(0.86-2.02)$ \\
\hline Excluding patients with & $2.70(2.08-3.50)$ & $1.52(1.15-2.01)$ & $1.26(0.89-1.79)$ \\
varices (3944) & & & $1.10(0.75-1.61)$ \\
\hline Excluding patients on & $2.82(2.13-3.73)$ & $1.41(1.04-1.91)$ & \\
aspirin (3036) & & & $\mathbf{1 . 2 8 ( 0 . 9 4 - 1 . 7 4 )}$ \\
\hline Total (4370) & $\mathbf{2 . 7 1 ( 2 . 1 4 - 3 . 4 2 )}$ & $\mathbf{1 . 5 0 ( 1 . 1 7 - 1 . 9 2 )}$ & \\
\hline
\end{tabular}

${ }^{*} \mathrm{n}$ is dependent on number of cases with complete and usable data for all components of logistic regression. Missing data vary between outcomes making $n$ variable. 